\title{
InSe Crystals Obtained by Stoichiometric Fusion for Optoelectronic Device Application
}

\author{
M. Aitzhanov, N. Guseinov, R. Nemkayeva, Zh. Tolepov, O. Prikhodko, Ye. Mukhametkarimov*
}

Al-Farabi Kazakh National University, 71 al-Farabi Ave., 050040 Almaty, Kazakhstan

(Received 30 August 2021; revised manuscript received 20 October 2021; published online 25 October 2021)

\begin{abstract}
Indium selenide (InSe) crystals have attracted great attention in recent years because of rather high carrier mobility and wide tunability of the band gap which gives an opportunity to produce highly sensitive optoelectronic devices based on them. In this contribution, layered InSe crystals were obtained using stoichiometric fusion method. Analysis of XRD spectra showed that InSe crystals obtained by this method have a hexagonal crystal structure with cell parameters $a=b=4.04 \AA, c=16.64 \AA$, which corresponds to $\beta$-InSe. The results of Raman studies are in good agreement with the results published elsewhere. The proposed synthesis method is easier and faster comparing to classical methods, like Bridgman-Stockbarger technique. At the same time, it allows to obtain samples of $\beta$-InSe of rather high quality to perform various laboratory experiments for prototype electronic devices. To prove this, photosensitivity of a planar metalsemiconductor-metal (MSM) photodetector based on synthesized $\beta$-InSe crystals was demonstrated. Gold contacts were used to create a back-to-back Schottky diode. Scanning photocurrent microscopy technique was used to investigate the local sensitivity of the produced MSM photodetector. Observations indicate the produced photodetector as highly sensitive to small changes in the position of the illuminated area.
\end{abstract}

Keywords: Stoichiometric fusion method, Indium selenide, Metal-semiconductor-metal photodetector, Schottky junction, Scanning photocurrent microscopy.

DOI: 10.21272/jnep.13(5).05037

PACS numbers: 68.65. $-\mathrm{k}, 68.65 . \mathrm{Ac}, 73.40 . \mathrm{Sx}$

\section{INTRODUCTION}

Two-dimensional (2D) semiconductors based on post-transition metal chalcogenides currently have attracted great attention owing to their remarkable optical and optoelectronic properties [1-5]. One of the bright representatives of this family is layered indium selenide (InSe) [6,7]. Constructed by layer-by-layer arrangement of metal and chalcogen atoms with Se-InIn-Se alternation, each InSe layer is weakly (van-derWaals) bonded to neighboring one. Depending on stacking sequences of layers, hexagonal $\beta$-, $\mathcal{E}$ - and rhombohedral $\gamma$-polytypes of InSe exist. From the point of view of optoelectronic applications, $\beta$-InSe and $\gamma$-InSe are of greater interest due to the direct band gap of $\sim 1.28 \mathrm{eV}$ at room temperature $[8,9]$. In recent years, many research works have been focused on the production of metal-semiconductor-metal (MSM) photodetectors based on thin layers of InSe and heterostructured photodetectors constructed using a combined stack of InSe and other 2D materials, in which significant advances have been achieved [10-15]. The main and actual problem for today is the ambient stability of fabricated photodetectors $[16,17]$. To solve this problem, photodetectors were encapsulated with hexagonal boron nitride (h-BN), polymethylmethacrylate (PMMA) and other isolator materials $[18,19]$. It should be noted that lateral MSM photodetectors are sensitive to local illumination. A small sub-micron scale displacement of the light spot can significantly change the photocurrent flowing through the structure. This opens up the possibility of using such MSM photodetectors as position-sensitive devices (PSD), which is important for the modern metrology area. In recent research works, the position-sensitive characteristics of lateral MSM photodetectors based on different 2D nanomaterials have been demonstrated [20,21].
InSe crystal could be obtained by different methods, such as Bridgman-Stockbarger technique, chemical vapor deposition or gas transport method, as well as various methods of epitaxial growth $[2,8]$. In this contribution, high quality $\beta$-InSe crystals were obtained by a simple stoichiometric fusion method using a vertical single-zone furnace with a rather high cooling rate. In a number of works, crystals obtained by a similar method were exfoliated in the liquid phase and further used in photocatalytic and electrochemical applications [22, 23]. Here we show that the application of such crystals can also be extended to optoelectronic applications. In particular, the photosensitivity of an Au-InSe-Au photodetector with a back-to-back Schottky junction was investigated under local illumination and using scanning photocurrent microscopy technique. As a result of the investigations, it was shown that $\beta$-InSe crystals obtained by the proposed method could be used for the creation of optoelectronic devices on a laboratory scale.

\section{EXPERIMENTS AND METHODS}

\subsection{InSe Crystal Growth}

A layered InSe crystal was obtained by fusing a stoichiometric amount of high purity In and Se particles, inserted into a pre-cleaned quartz ampoule evacuated to high vacuum $\left(\sim 10^{-3} \mathrm{~Pa}\right)$ and sealed. Fusion was carried out using a vertical furnace at $780{ }^{\circ} \mathrm{C}$ for $1 \mathrm{~h}$. Then, the ampoule with the molten elements was cooled at a rate of $1^{\circ} \mathrm{C} / \mathrm{min}$ until $500^{\circ} \mathrm{C}$, further cooling down to room temperature was natural. Note that the cooling rate used in this work is significantly faster than the traditional Bridgman-Stockbarger method. As a result, the sample thus grown has a polycrystalline microstructure.

\footnotetext{
*yerzhan.mukhametkarimov@kaznu.kz
} 


\subsection{Characterization of InSe Crystal}

The crystal structure was investigated by X-ray structural analysis equipment (Rigaku) and a Raman spectrometer (Solver Spectrum NT-MDT). The study of the composition and morphology of $2 \mathrm{D}$ InSe layers was carried out using energy-dispersive X-ray spectroscopy (EDS) on a scanning electron microscope (Quanta 3D 200i), atomic force and optical microscope (Solver Spectrum, NT-MDT).

\subsection{Production of Photodetector}

To produce MSM photodetectors, the initial InSe crystals were exfoliated micromechanically using an adhesive tape and transferred to a quartz substrate. Then thin gold contacts were deposited through a mask into the chosen multilayer InSe. Typical thickness of layered InSe flakes measured using AFM was ranged from 200 to $300 \mathrm{~nm}$, and the distance between Au electrodes was $35 \mu \mathrm{m}$. A typical optical microscope image of an InSe flake with a thickness of about $250 \mathrm{~nm}$ according to the cross section determined using AFM and a schematic illustration of the produced Au-InSe-Au MSM photodetector are shown in Fig. 2.

\subsection{Photocurrent Measurements}
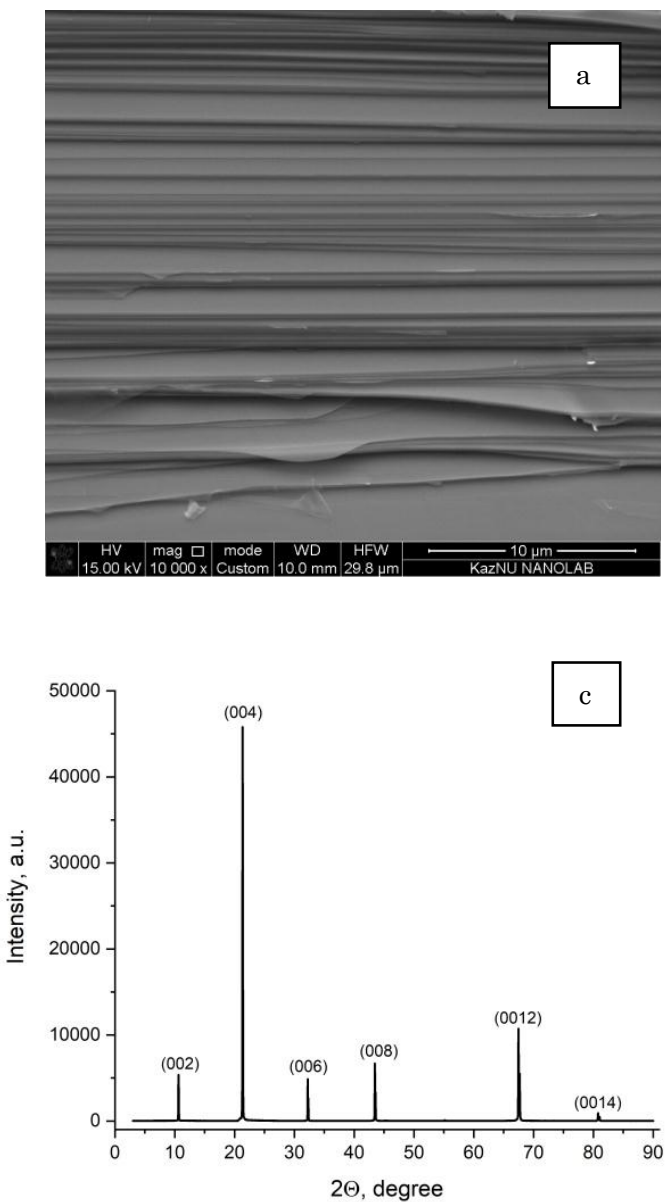

A comprehensive study of the current-voltage (I-V) characteristic was carried out at room temperature using equipment consisting of a Keithley 6517A electrometer and a DC power supply. $I-V$ characteristics as a function of illumination were obtained using a $532 \mathrm{~nm}$ laser source together with a combined equipment of a Raman spectrometer and an AFM microscope with an $X-Y$ step driver for small displacement of the sample.

\section{RESULTS AND DISCUSSION}

Fig. 1a shows the microstructure of thick InSe flakes, where it is clearly seen a layered arrangement. EDS analysis shows that the crystals have the required stoichiometric composition. The values of the atomic ratios of the elements are 50.43 at. \% and 49.57 at. \% of indium and selenium, respectively. The EDS spectrum of InSe crystals is illustrated in Fig. 1b.

Fig. 1c shows the XRD pattern of thick InSe flakes. The measurement was carried out by X-ray diffraction analysis on a Rigaku X-ray analytical system using a CuKa monochromator. The analysis of the peaks shows that the obtained crystals have a hexagonal structure with the crystal lattice parameters $a=b=4.04 \AA$ and $c=16.64 \AA$ and symmetry space group $\mathrm{D}^{4} 6 \mathrm{~h}$. This result indicates that stacking sequences of layers in obtained InSe crystals correspond to $\beta$-polytype.
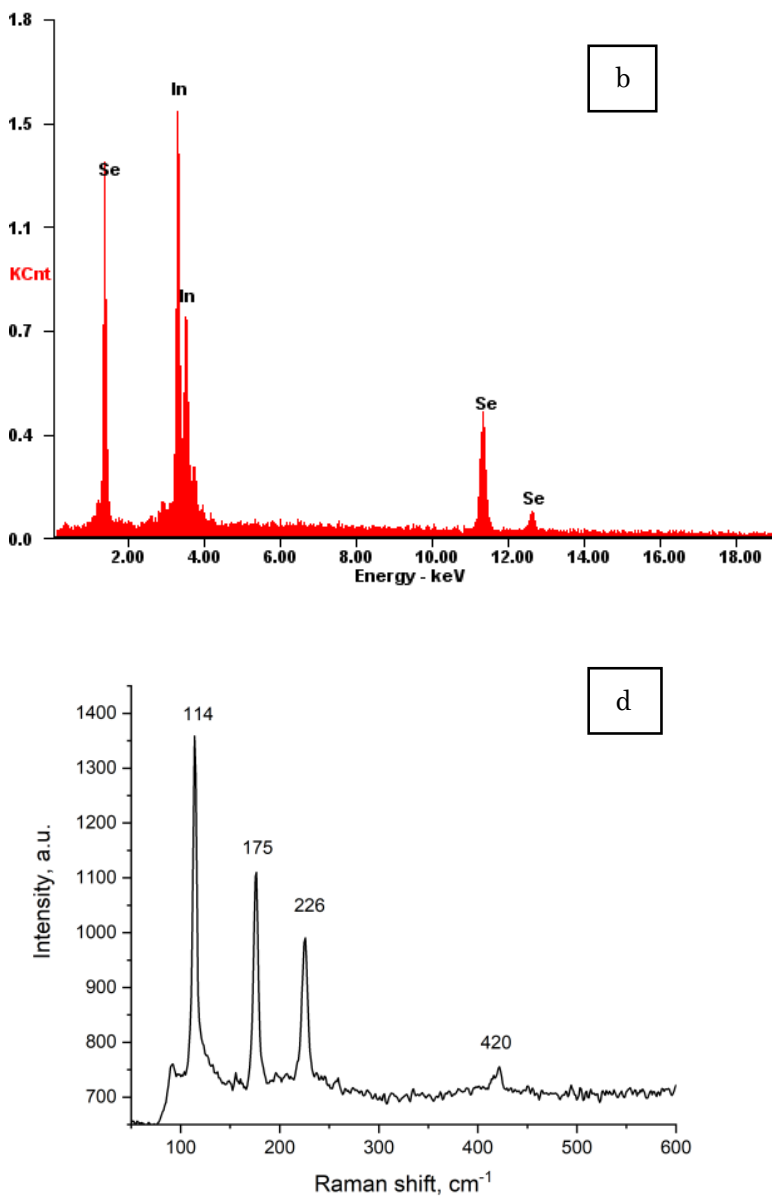

Fig. 1 - SEM image (a), EDS spectrum (b), XRD pattern (c) and Raman spectrum (d) of the obtained layered InSe crystals 

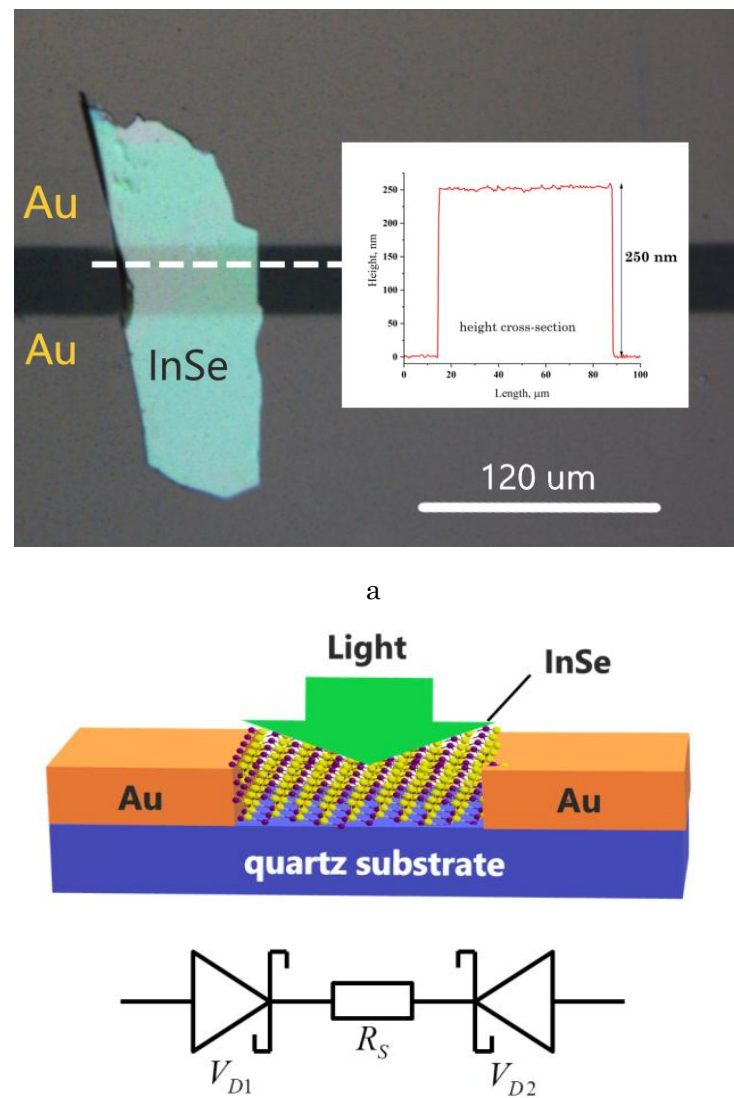

$\mathrm{b}$

Fig. 2-Optical microscope image with an AFM cross-section in height (a), schematic illustration of the produced MSM photodetector (b)

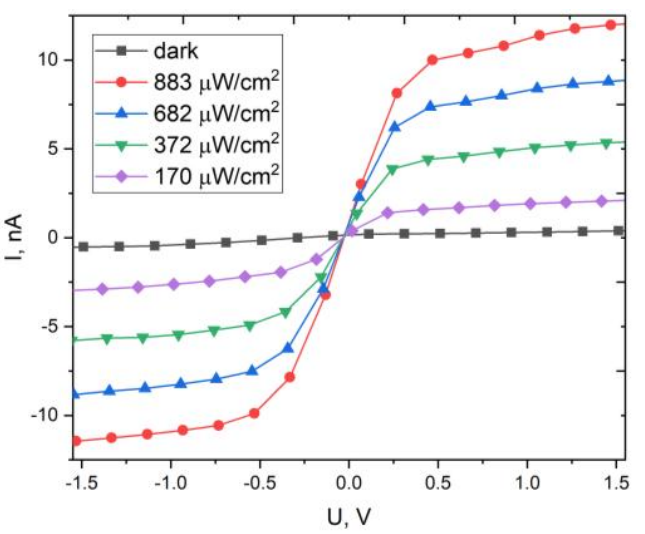

Fig. 3-I- $V$ characteristics of Au-InSe-Au photodetector under illumination

The Raman spectrum illustrated in Fig. 1d was recorded using a $473 \mathrm{~nm}$ laser. There are typical peaks at 114, 175 and $226 \mathrm{~cm}^{-1}$, which correspond to $\mathrm{A}_{\mathrm{g} 1}^{1}, \mathrm{E}_{2 \mathrm{~g}}$ and $\mathrm{A}_{\mathrm{g} 2}$ vibrational modes, respectively. An additional peak at $420 \mathrm{~cm}^{-1}$ belongs to the second order of the $E$ mode [24, 25].

Fig. 3 shows the $I-V$ characteristics of $\mathrm{Au}-\mathrm{InSe}-\mathrm{Au}$ photodetector as a function of bias voltage $(U)$ obtained in the dark and under $532 \mathrm{~nm}$ illumination with different intensities. The dark current does not exceed a few $\mathrm{nA}$ for the whole range of bias voltages. As can be seen from the figure, an increase in the illumination intensity leads to an increase in the drain-source current $(I)$ flowing through the structure. These $I-V$ characteristics correspond to the reverse currents of back-to-back Schottky diodes as illustrated in Fig. 2c. According to many studies [9-10,13], the typical work function of InSe thick crystals is about $4.55-4.77 \mathrm{eV}$. The hot probe measurements have shown that the obtained bulk InSe crystal has $n$-type conductivity. Its contact with $\mathrm{Au}$ electrodes (work function is more than $5.1 \mathrm{eV}$ ) leads to the creation of a Schottky junction at the metal-semiconductor interfaces. The band diagram of such a junction is illustrated in Fig. 4. In contrast to common photodiodes, the constructed device can operate regardless of the polarity of the input voltage.

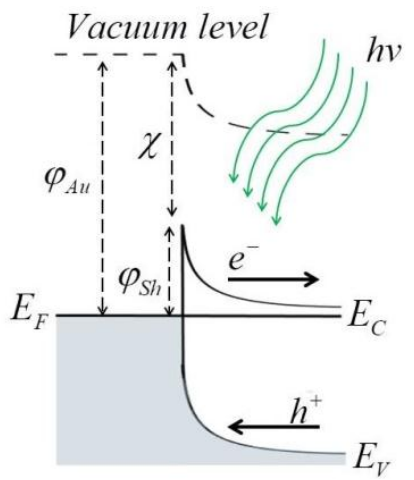

Fig. 4 - Energy band diagram of a Schottky diode based on an $n$-type semiconductor and a metal

The produced photodetectors as expected were sensitive to local illumination. Fig. 5 shows the $I-V$ characteristics under local illumination using a $532 \mathrm{~nm}$ laser focused into a $2 \mu \mathrm{m}$ spot. The branches illustrated in this figure correspond to illumination in the right (red curve), left (blue curve) contact areas and the exact central area (black curve) between the two contacts.

Fig. 6 shows the results of scanning photocurrent microscopy. This measurement was carried out in the short-circuit regime. As can be seen, a small displacement of the light spot leads to rather large changes in the photocurrent value. This observation suggests that such MSM photodetectors can be used as positionsensitive devices.

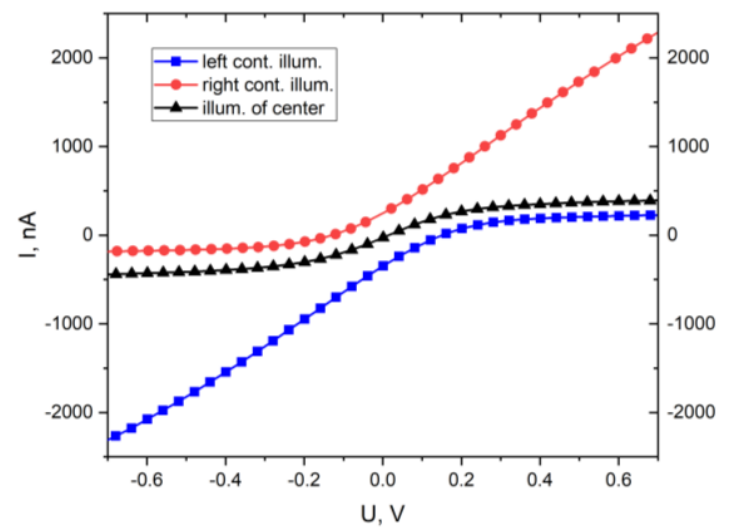

Fig. 5 - I- $V$ characteristics of Au-InSe-Au photodetector under local illumination 


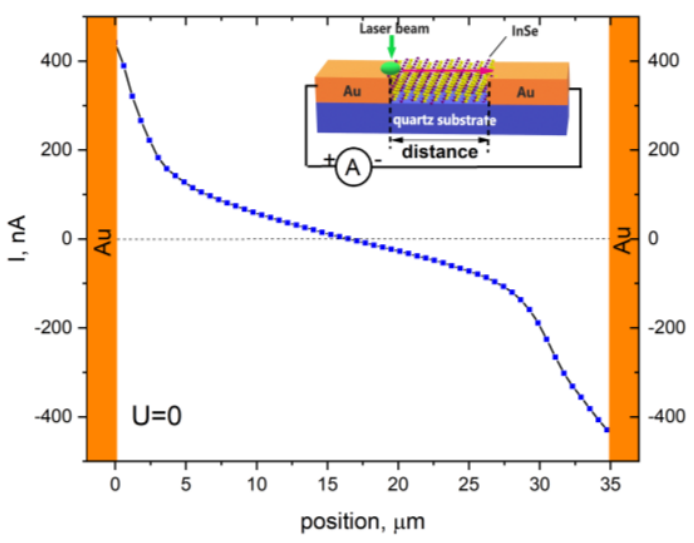

Fig. 6 - Scanning photocurrent microscopy of Au-InSe-Au photodetector

\section{REFERENCES}

1. W. Huang, L. Gan, H. Li, Y. Ma, T. Zhai, Cryst. Eng. Comm 18, 3968 (2016).

2. H. Arora, A. Erbe, InfoMat 3 No 6, 662 (2021).

3. W. Jie, X. Chen, D. Li, L. Xie, Ye.Y. Hui, S.P. Lau, X. Cui, J. Hao, Angew. Chem. Int. Ed 54 No 4, 1185 (2014).

4. Y. Sun, S. Luo, X.-G. Zhao, K. Biswas, S.-L. Li, L, Zhang, Nanoscale 10, 7991 (2018).

5. A. Politano, D. Campi, M. Cattelan, I.B. Amara, S. Jaziri, A. Mazzotti, A. Barinov, B. Gürbulak, S. Duman, S. Agnoli, L.S. Caputi, G. Granozzi, A. Cupolillo, Sci. Rep. 7, 3445 (2017).

6. D.A. Bandurin, A.V. Tyurnina, G.L. Yu, A. Mishchenko, V. Zólyomi，S.V. Morozov， R.K. Kumar， R.V. Gorbachev, Z.R. Kudrynskyi, S. Pezzini, Z.D. Kovalyuk, U. Zeitler, K.S. Novoselov, A. Patanè, L. Eaves, I.V. Grigorieva, V.I. Fal'ko, A.K. Geim, Y. Cao, Nature Nanotech 12 No 3, 223 (2017).

7. C. Song, F.-R. Fan, N. Xuan, S. Huang, G. Zhang, C. Wang, Z. Sun, H. Wu, H. Yan, ACS Appl. Mater. Interfaces 10 No 4, 3994 (2018).

8. D.W. Boukhvalov, B. Gürbulak, S. Duman, L. Wang, A. Politano, L.S. Caputi, G. Chiarello, A. Cupolillo, Nanomaterials 7, 372 (2017).

9. D.K. Sang, H. Wang, M. Qiu, R. Cao, Z. Guo, J. Zhao, Y. Li, Q. Xiao, D. Fan, H. Zhang, Nanomaterials 9, 82 (2019).

10. S. Hu, Q. Zhang, X. Luo, X. Zhang, T. Wang, Y. Cheng, W. Jie, J. Zhao, T. Meia, X. Gan, Nanoscale 12, 4049 (2020).

11. D.J. Terry, V. Zólyomi, M. Hamer, A.V. Tyurnina, D.G. Hopkinson, A.M. Rakowski, S.J. Magorrian, N. Clark, Y.M. Andreev, O. Kazakova, 2D Mater. 5, 041009 (2018).

12. L. Liu, L. Wu, A. Wang, H. Liu, R. Ma, K. Wu, J. Chen, Z. Zhou, Y. Tian, H. Yang, C. Shen, L. Bao, Z. Qin, S.T. Pantelides, H.-J. Gao, Nano Lett. 20 No 9, 6666 (2020).

\section{CONCLUSIONS}

A simple technology for producing layered crystals of InSe based on stoichiometric fusion of In and Se particles has been developed. The analysis of the XRD patterns shows that the grown crystals have a hexagonal structure with the symmetry space group $\mathrm{D}^{4} 6 \mathrm{~h}$ and correspond to $\beta$-polytype of InSe crystals. It is important to note that an MSM photodetector made from a synthesized InSe flake has good light-sensitive characteristics, which means that the proposed InSe growth technique is efficient enough for the production of laboratory prototypes of optoelectronic devices.

\section{ACKNOWLEDGEMENTS}

This work was supported by the grant AP08052085 funded by the Committee of Science of the Ministry of Education and Science of the Republic of Kazakhstan.

13. Q. Zhao, W. Jie, T. Wang, A. Castellanos-Gomez, R. Frisenda, Adv. Fun. Mat. 30, 2001307 (2020).

14. Z. Yang, W. Jie, C.-H. Mak, S. Lin, X. Yang, F. Yan, S.P. Lau, J. Hao, ACS Nano 11 No 4, 4225 (2017).

15. Q. Zhao, T. Wang, R. Frisenda, A. Castellanos-Gomez, Adv. Sci. 7 No 20, 2001645 (2020).

16. Y. Wang, J. Gao, B. Wei, Y. Han, C. Wang, Y. Gao, H. Liu, L. Han, Y. Zhang, Nanoscale 12, 18356 (2020).

17. P.-H. Ho, Y.-R. Chang, Y.-C. Chu, M.-K. Li, C.-A. Tsai, W.-H. Wang, C.-H. Ho, C.-W. Chen, P.-W. Chiu, ACS Nano 11 No 4, 7362 (2017).

18. J. Jiang, J. Li, Y. Li, J. Duan, L. Li, Y. Tian, Z. Zong, H. Zheng X. Feng, Q. Li, H. Liu, Y. Zhang, T.-L. Ren, L. Han, npj $2 D$ Mater. Appl. 3, 29 (2019).

19. Q. Zhao, F. Carrascoso, P. Gant, T. Wang, R. Frisenda, A. Castellanos-Gomez, J. Phys. Mater. 3, 036001 (2020).

20. C. Hu, X. Wang, B. Song, Light Sci. Appl. 9, 88 (2020).

21. N. Ubrig, S. Jo, H. Berger, A.F. Morpurgo, A.B. Kuzmenko, Appl. Phys. Let. 104, 171112 (2014).

22. M.I. Zappia, G. Bianca, S. Bellani, M. Serri, L. Najafi, R. Oropesa-Nuñez, B. Martín-García, D. Bouša, D. Sedmidubský, V. Pellegrini, Z. Sofer, A. Cupolillo, F. Bonaccorso, Adv. Funct. Mater. 30, 1909572 (2020).

23. S.M. Tan, C.K. Chua, D. Sedmidubský, Z. Sofer, M. Pumera, Phys. Chem. Chem. Phys. 18, 1699 (2016).

24. J.F. Sánchez-Royo, G. Muñoz-Matutano, M. Brotons-Gisbert, J.P. Martínez-Pastor, A. Segura, A. Cantarero, R. Mata, J. Canet-Ferrer, G. Tobias, E. Canadell, J. Marqués-Hueso, B. D. Gerardo, Nano Res 7, 1556 (2014).

25. S.R. Tamalampudi, R. Sankar, H. Apostoleris, M.A. Almahri, B. Alfakes, A. Al-Hagri, R. Li, A. Gougam, I. Almansouri, M. Chiesa, J.-Y. Lu, J. Phys. Chem. C 123, 15345 (2019).

\title{
Кристали InSe, отримані стехіометричним плавленням, для застосування в оптоелектронних пристроях
}

\author{
M. Aitzhanov, N. Guseinov, R. Nemkayeva, Zh. Tolepov, O. Prikhodko, Ye. Mukhametkarimov
}

Al-Farabi Kazakh National University, 71 al-Farabi Ave., 050040 Almaty, Kazakhstan

Кристали селеніду індію (InSe) привертають велику увагу останнім часом через досить високу рухливість носіїв та широку переналаштовуваність забороненої зони, що дає можливість виробляти високочутливі оптоелектронні пристрої на їх основі. У роботі шаруваті кристали InSe були отримані за допомогою методу стехіометричного плавлення. Аналіз спектрів XRD показав, що кристали InSe, 
отримані цим методом, мають гексагональну кристалічну структуру з параметрами елементарної комірки $a=b=4,04 \AA$ та $c=16,64 \AA$, що відповідае $\beta$-InSe. Результати раманівських досліджень добре узгоджуються з іншими опублікованими результатами. Запропонований метод синтезу е простішим $\mathrm{i}$ швидшим порівняно з класичними методами, такими як техніка Бріджмана-Стокбаргера. Водночас він дозволяе отримувати зразки $\beta$-InSe досить високої якості для виконання різних лабораторних експериментів для прототипів електронних пристроїв. На підтвердження цього було продемонстровано фоточутливість плоского фотодетектора метал-напівпровідник-метал (MSM) на основі синтезованих кристалів $\beta$-InSe. Золоті контакти були використані для створення зустрічно-включеного діода Шотткі. Метод скануючої фотострумової мікроскопії був використаний для дослідження локальної чутливості виробленого фотодетектора MSM. Спостереження вказують на виготовлений фотоприймач як на дуже чутливий до невеликих змін у положенні освітлюваної області.

Ключові слова: Метод стехіометричного плавлення, Селенід індію, Фотоприймач метал-напівпровідник-метал, Перехід Шотткі, Скануюча фотострумова мікроскопія. 